\title{
Effect of dietary proteins on insulin-like growth factor-1 (IGF-1) messenger ribonucleic acid content in rat liver
}

\author{
BY YUTAKA MIURA, HISANORI KATO AND TADASHI NOGUCHI \\ Department of Agricultural Chemistry, Faculty of Agriculture, University of Tokyo, \\ Bunkyo-ku, Tokyo 113, Japan
}

(Received 5 October 1990-Accepted 25 March 199I)

Effects of quantity and quality of dietary proteins on plasma immunoreactive insulin-like growth factor-1 (IGF-1) concentration, and content of IGF-1 mRNA in rat liver were investigated in rats. Plasma immunoreactive IGF-1 concentration in rats given a casein diet was higher than that in rats given a soya-bean-protein or protein-free diet. The IGF-1 mRNA content in liver was estimated by the Northern blot hybridization technique employing ${ }^{32} \mathrm{P}$-labelled rat IGF-1 complementary DNA (cDNA). At least four molecular species of IGF-1 mRNA of different molecular weight were found in rat liver. The sizes were $0.8-1 \cdot 2,2.0,3.6-4.0$ and $7.4 \mathrm{~kb}$. Most of the mRNA species decreased in the livers of rats given a gluten diet $(120 \mathrm{~g}$ gluten $/ \mathrm{kg}$ diet) compared with rats given the casein diet. In particular, $\mathrm{mRNA}$ of $7.4 \mathrm{~kb}$ decreased markedly. When rats were fed on the protein-free diet, mRNA of all species decreased significantly. The estimated IGF-1 mRNA in the livers of rats fed on the gluten or proteinfree diet was almost 0.4 of that of the rats given the casein diet. Feeding the soya-bean-protein diet did not result in a marked effect on the hepatic content of mRNA species of IGF-1. The results showed that liver IGF-1 mRNA content is sensitively regulated by quantity and nutritional quality of dietary proteins.

Insulin-like growth factor-1 : Dietary protein: Insulin-like growth factor-1 mRNA: Liver: Rat

Insulin-like growth factor-1 (IGF-1; also referred to as somatomedin C) is a peptide hormone containing seventy amino acid residues (Rinderknecht \& Humbel, 1978) which shows insulin-like activity on many kinds of cells (Van Wyk, 1984). IGF-1 also induces cell proliferation (Van Wyk, 1984).

When growth hormone $(\mathrm{GH})$ is injected into hypophysectomized rats, the plasma concentration of IGF-1 increases significantly (Froesch et al. 1985), indicating that plasma IGF-1 concentration is regulated by GH. It has also been shown that the plasma concentration of IGF-1 is regulated by the quantity and nutritional quality of dietary proteins (Phillips et al. 1978; Prewitt et al. 1982; Isley et al. 1983; Takahashi et al. 1990). Furthermore, when hypophysectomized rats are given a low-protein diet, plasma IGF-1 concentration does not increase significantly even after GH administration (Maes et al. 1988). This absence of response to $\mathrm{GH}$ was referred to as $\mathrm{GH}$ resistance. The results are further evidence that synthesis and secretion of IGF-1 are influenced by dietary proteins.

Although IGF-1 is synthesized in various tissues (D'Ercole et al. 1984), plasma IGF-1 has been shown to be secreted primarily by liver (Schwander et al. 1983). These results strongly suggest that synthesis and secretion of IGF-1 by liver are influenced by dietary proteins, possibly through transcriptional and translational control mechanisms.

Several molecular species of IGF-1 mRNA have been reported in the liver (Roberts $e t$ al. 1986; Murphy et al. 1987). However, the physiological significance of each mRNA has not been elucidated. If nutritional factors affect the amounts of various mRNA species of IGF-I, the nutritional or physiological significance of mRNA species may be predicted. In 
this context, we have attempted to elucidate the effect of the quantity and quality of dietary proteins on the total amount of IGF-1 mRNA or on the amount of various species of IGF-1 mRNA in rat liver.

\section{MATERIALS AND METHODS}

\section{Animals and diets}

Expt 1. Male Wistar rats (mean initial body-weight 140.7 (SE 0.7) g, $n 15$ ) were obtained from Shizuoka Agricultural Cooperative for Laboratory Animals (now Japan SLC Co.) (Hamamatsu) and were fed on a casein-based $(120 \mathrm{~g} / \mathrm{kg}$; diet C), gluten-based $(120 \mathrm{~g} / \mathrm{kg}$; diet $\mathrm{G}$ ) or protein-free (PF) diet for 1 week. The composition of the diets is shown in Table 1. The rats were offered water ad lib. but the diets were offered from 10.00 to 18.00 hours. On day 8 , the rats were fed at 10.00 hours and killed at 11.30 hours by taking arterial blood under pentobarbital anaesthesia ( $50 \mathrm{mg}$ pentobarbital $/ \mathrm{kg}$ body-weight). The livers of the rats were excised quickly and placed in liquid nitrogen.

Expt 2. Male Wistar rats (initial body-weight 1106 (SE 1.23) g, $n$ 24) were purchased from Japan SLC Co. (Hamamatsu). They were divided into four groups of six rats each and fed on diets containing casein (diet C), isolated soya-bean protein (diet ISP), isolated soya-bean protein supplemented with methionine (diet ISPM) and no protein (diet PF). The composition of the diets is shown in Table 1. The isolated soya-bean protein was obtained from Fuji Seiyu Co. (Izumisano City, Osaka). The diets were fed ad lib. for $7 \mathrm{~d}$. On the 8th day at about 11.30 hours, the rats were lightly anaesthetized with pentobarbital as described previously and blood was collected with decapitation. Blood coagulation was prevented by EDTA as directed by the manufacturers of the IGF-1 assay kit (Nichols Institute, CA, USA). The liver was quickly excised, frozen in liquid $\mathrm{N}_{2}$ and kept at $-80^{\circ}$ until the time of RNA preparation.

\section{Radioimmunoassay of plasma IGF-1}

Plasma immunoreactive IGF-1 concentration was determined as described previously (Takahashi et al. 1990) employing a human IGF-1 assay kit (Nichols Institute, CA, USA). The total IGF-1 concentration (immunoreactive IGF-1 concentration after acid-ethanol extraction; Takahashi et al. 1990) was also measured.

\section{Northern blot analysis of IGF-1 $m R N A$}

Liver RNA was prepared according to Chomczynski \& Sacchi (1987). In brief, 02 g liver was dissected into small pieces using scissors in $1 \mathrm{ml}$ of a 'denaturing solution' (Solution D of Chomczynski \& Sacchi, 1987) and homogenized using a Dounce-type homogenizer with a Teflon pestle. To this homogenate, $0.1 \mathrm{ml} 2 \mathrm{M}$-sodium acetate $(\mathrm{pH} 4.0), 1.0 \mathrm{ml}$ phenol (water saturated), and $0.2 \mathrm{ml}$ chloroform-isoamyl alcohol $(49: 1 \mathrm{v} / \mathrm{v})$ were added and the mixture mixed thoroughly. After leaving the mixture for $15 \mathrm{~min}$ on ice, it was centrifuged at $10000 \mathrm{~g}$ for $20 \mathrm{~min}$. The water phase was mixed with an equal volume of propan-2-ol and the precipitated RNA was collected by centrifugation at $10000 \mathrm{~g}$ for $20 \mathrm{~min}$. The RNA was dissolved in Solution $\mathrm{D}$ and precipitated again by the same procedure. This RNA preparation was washed with ethanol $(750 \mathrm{~g} / 1)$, dried in vacuo and dissolved in distilled water (previously treated with diethylpyrocarbonate) at $65^{\circ}$ for $10 \mathrm{~min}$. The concentration of RNA in this solution was determined by the absorbance at $260 \mathrm{~nm}$. Total RNA $(50 \mu \mathrm{g})$ was subjected to electrophoresis in an agarose $(15 \mathrm{~g} / 1)-2 \cdot 2 \mathrm{M}$-formaldehyde gel at $180 \mathrm{~V}$ for $3 \mathrm{~h}$ and transferred to a nitrocellulose filter (Advantec TOYO, Tokyo, Japan) according to a generally used method (Maniatis et al. 1982). The filter was baked at $80^{\circ}$ for $2 \mathrm{~h}$ in vacuo. The filters were prehybridized for $12 \mathrm{~h}$ at $42^{\circ}$ in a solution containing: formamide 
Table 1. The composition of the experimental diets $(\mathrm{g} / \mathrm{kg})$

\begin{tabular}{|c|c|c|c|c|c|}
\hline Diets... & Protein-free & Gluten & $\begin{array}{l}\text { Soya-bean } \\
\text { protein }\end{array}$ & $\begin{array}{l}\text { Soya-bean protein } \\
+ \text { methionine }\end{array}$ & Casein \\
\hline \multicolumn{6}{|l|}{ Ingredients } \\
\hline$\beta$-Maize starch & 850 & 720 & $723 \cdot 4$ & $723 \cdot 3$ & 728 \\
\hline Gluten & - & 120 & - & - & - \\
\hline $\begin{array}{l}\text { Soya-bean protein (crude protein } \\
\text { (nitrogen } \times 6.25) 920 \mathrm{~g} / \mathrm{kg} \text { ) }\end{array}$ & - & - & 121 & 121 & - \\
\hline Casein & - & - & - & - & 120 \\
\hline L-methionine & - & - & - & $3 \cdot 2$ & $2 \cdot 0$ \\
\hline L-threonine & - & - & $1 \cdot 5$ & $1 \cdot 5$ & - \\
\hline L-lysine monohydrochloride & - & - & $1 \cdot 0$ & $1 \cdot 0$ & - \\
\hline L-glutamic acid & - & 10 & $3 \cdot 1$ & - & - \\
\hline
\end{tabular}

In addition to these components, all diets contained $(\mathrm{g} / \mathrm{kg})$ : soya-bean oil 50 , cellulose 50 , mineral mixture 40 and vitamin mixture 10 . The mineral and vitamin mixtures were purchased from Oriental Yeast Co. (Tokyo, Japan; Expt 1) and from Nihon Nosan Co. (Yokohama, Japan; Expt 2). The mixtures in Expt 1 were formulated according to Rogers \& Harper (1965) and those in Expt 2 to the American Institute of Nutrition (1977).

(400 ml/1), $20 \mathrm{~mm}$-sodium dihydrogen phosphate, four times concentrated standard sodium citrate (SSC; the original SSC contained $0 \cdot 15 \mathrm{M}$-sodium chloride, $0 \cdot 015 \mathrm{M}$-sodium citrate), five times concentrated Denhardt's solution (Denhardt's solution contained $0.2 \mathrm{~g} / 1$ of each of bovine serum albumin (BSA; Sigma), ficoll, and polyvinylpyrrolidone), and $100 \mathrm{mg}$ salmon testis DNA (Sigma product code D1626)/1. Hybridization was performed for $24 \mathrm{~h}$ at $42^{\circ}$ in the same solution with extra components, i.e. $100 \mathrm{~g}$ dextran sulphate (Sigma)/1 and ${ }^{32} \mathrm{P}$-labelled rat IGF-1 complementary DNA (cDNA) $\left(3 \times 10^{6}\right.$ counts $/ \mathrm{min}(\mathrm{cpm})$. After hybridization the filters were washed at $65^{\circ}$ for $1 \mathrm{~h}$ with two times concentrated SSC with $10 \mathrm{~g}$ sodium dodecylsulphate (SDS)/1. Then the filters were again washed for $1 \mathrm{~h}$ at room temperature in the same solution. Finally the filters were autoradiographed at $-70^{\circ}$ in a Fuji EC-A cassette (Fuji film Co., Tokyo, Japan) equipped with an intensifying screen. IGF-1 cDNA was obtained by screening a rat liver cDNA library (Clontech) using a synthetic oligonucleotide DNA probe. The details of the method have been reported (Kato et al. $1990 \mathrm{~b}$ ). The cDNA contained the coding sequence, $5^{\prime}$-untranslated region of class $\mathrm{A}$ type and a part of $3^{\prime}$-untranslated region. This cDNA was labeled with ${ }^{32} \mathrm{P}$-labelled dCTP (3000 $\mu \mathrm{Ci} / \mathrm{mmol}$; New England Nuclear) employing a nick translation kit (Takara, Kyoto, Japan). The final product contained $3.0 \times 10^{7} \mathrm{cpm} / \mu \mathrm{g}$ DNA. The intensity of the spots on the film after autoradiography was measured using a densitometer (Computing densitometer ACD-18, ATTO).

\section{Statistical analysis}

The differences among the means were analysed by one-way analysis of variance and Tukey's Q test (Snedecor \& Cochran, 1967).

\section{RESULTS}

Supplementation of soya-bean-protein diet with methionine, threonine and lysine (diet ISPM) increased significantly the immunoreactive IGF-1 concentration and immunoreactive: total IGF-I in plasma (Table 2). The effect of supplementation of the deficient amino acids is not due to the increase in food (or energy) intake because the supplemented group (diet ISPM) had a lower food intake than the unsupplemented group (diet ISP). Furthermore, the effect of protein deprivation was not due to the difference in food intake 
Table 2. Expt 2. Body-weight changes and plasma immunoreactive (im-IGF-I) and total insulin-like growth factor-1 ( $t-I G F-I)$ concentrations in the rats fed on various protein sources* $^{*}$

(Values are means for six rats)

\begin{tabular}{|c|c|c|c|c|c|}
\hline \multirow[b]{2}{*}{ Diet } & \multirow[b]{2}{*}{$\begin{array}{l}\text { Body-wt gain } \\
\quad(\mathrm{g} / 8 \mathrm{~d})\end{array}$} & \multirow[b]{2}{*}{$\begin{array}{l}\text { Food intake } \\
\qquad(\mathrm{g} / \mathrm{d})\end{array}$} & \multicolumn{3}{|c|}{ Plasma concentration of: } \\
\hline & & & $\begin{array}{c}\mathrm{im}-\mathrm{IGF}-1 \\
(\mathrm{U} / \mathrm{ml})\end{array}$ & $\begin{array}{l}\text { t-IGF-1 } \\
(\mathrm{U} / \mathrm{ml})\end{array}$ & im-IGF-1:t-IGF-l \\
\hline Casein & $41 \cdot 7^{\mathrm{be}}$ & $14 \cdot 6^{\mathrm{bc}}$ & $6 \cdot 60^{\circ}$ & $24 \cdot 5^{\mathrm{c}}$ & $0 \cdot 29^{\mathrm{b}}$ \\
\hline $\begin{array}{l}\text { Soya-bean protein with } \\
\text { methionine } \dagger\end{array}$ & $36-2^{\circ}$ & $12 \cdot 7^{a 11}$ & $5 \cdot 73^{\prime}$ & $18 \cdot 9^{\mathrm{he}}$ & $0.31^{b}$ \\
\hline Soya-bean protein $\uparrow$ & $24 \cdot 5^{b}$ & $15 \cdot 0^{\prime}$ & $2 \cdot 58^{b}$ & $12 \cdot 9^{\mathrm{ab}}$ & $0 \cdot 20^{\mathrm{a}}$ \\
\hline Protein-free & $-9 \cdot 9^{a}$ & $10 \cdot 6^{a}$ & $1 \cdot 20^{:}$ & $7 \cdot 0^{\mathrm{a}}$ & $0 \cdot 17^{\mathrm{a}}$ \\
\hline Residual mean square & $38 \cdot 8$ & 19 & $0 \cdot 30$ & $38 \cdot 8$ & 0.0018 \\
\hline$F$ & $81 \cdot 4$ & $13 \cdot 1$ & 130 & $8 \cdot 7$ & $13 \cdot 1$ \\
\hline $\begin{array}{l}\text { Statistical significance of } \\
\text { effect of diet: } P\end{array}$ & $<0.001$ & $<0.01$ & $<0 \cdot 001$ & $<0.01$ & $<001$ \\
\hline
\end{tabular}

a, b,، Values with unlike superscript letters were significantly different $(P<0.05)$ by Tukey’s $Q$ test (Snedecor \& Cochran, 1967).

* For details, see p. 258.

$\uparrow$ These diets contained supplemental lysine and threonine (for details, see Table 1).

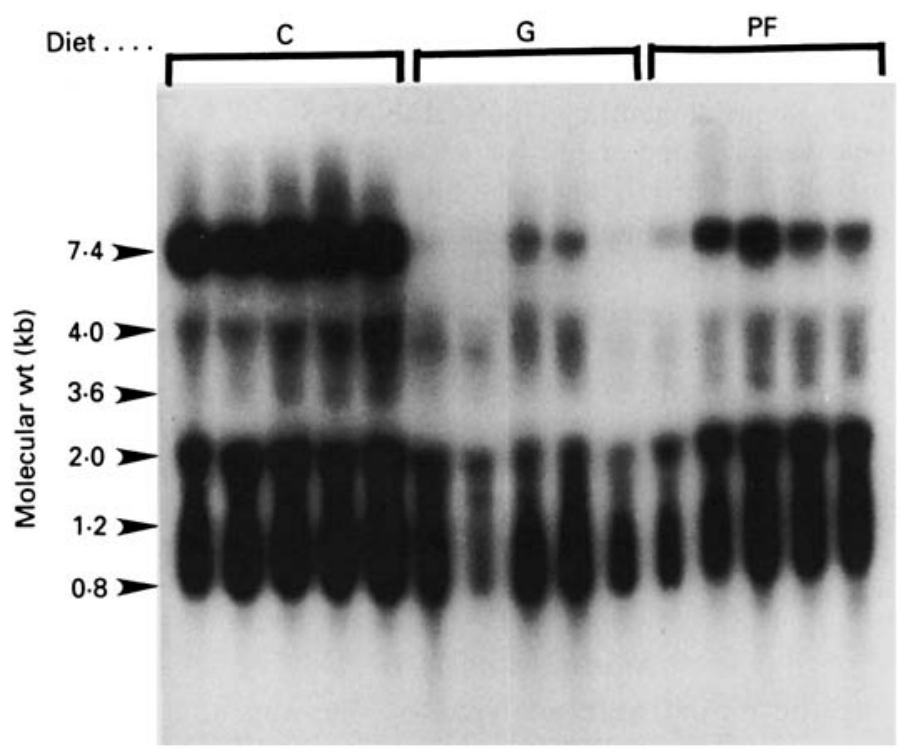

Fig. 1. Northern blot analysis of liver insulin-like growth factor-1 (IGF-1) messenger RNA (mRNA) from rats given a casein $(C)$, gluten $(G)$ or protein-free $(P F)$ diet. Each lane shows the mRNA of one rat. For the quantitative analysis of the results, see Table 3 . For details of diets, see Table 1 and p. 258, and for details of procedures, see p. 259 .

because there was no difference in food intake between the groups receiving diets ISPM and $\mathrm{PF}$.

Fig. 1 shows that the livers of the rats given diet $C$ had the highest levels of IGF- 1 mRNA among the three groups of rats. Densitometric analysis of the autoradiogram (Table 3, Expt 


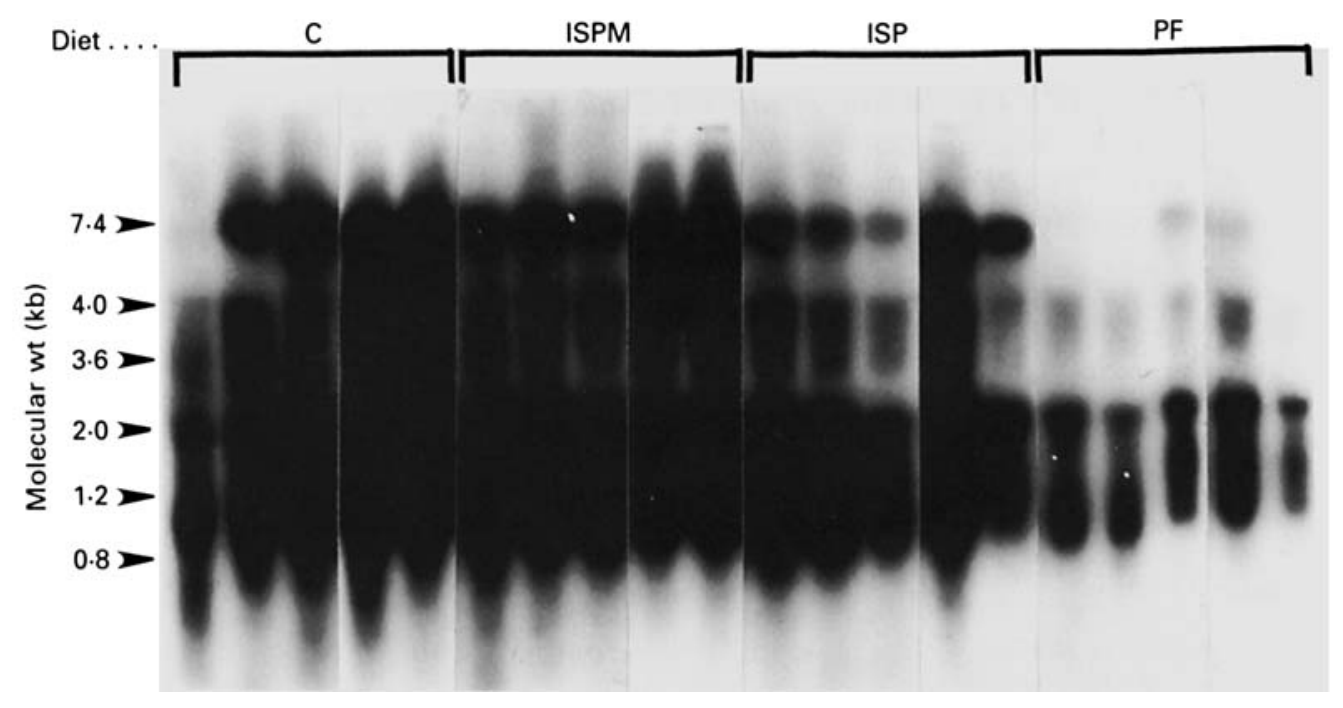

Fig. 2. Northern blot analysis of liver insulin-like growth factor-1 (IGF-1) messenger RNA (mRNA) from rats given a casein (C), soya-bean-protein (ISP), soya-bean-protein supplemented with methionine (ISPM), and protein-free (PF) diet. Each lane shows the mRNA of one rat. For the quantitative analysis of the results, see Table 3. For details of diets, see Table 1 and p. 258, and for details of procedures, see p. 259.

1) showed that the amounts of total IGF-1 mRNA in the livers of the rats given diet PF and diet $G$ were approximately 0.4 of that of rats fed on diet $C$. There was no significant difference between the two groups of rats fed on diets $G$ and PF. That this effect of diet on IGF-1 mRNA may be due, at least in part, to a difference in food intake cannot be ruled out because in this particular case, food intake was not recorded.

The total mRNA content did not differ significantly between the groups of rats fed on diets, C, ISP and ISPM (Fig. 2 and Table 3; Expt 2).

At least four IGF-1 mRNA species were found in rat liver (Figs 1 and 2). The effect of dietary proteins on each size of mRNA was different. The results of densitometric analysis of each band are shown in Table 3 . The bands of about $0.8-1.2 \mathrm{~kb}$ and about $3.6-4 \cdot 0 \mathrm{~kb}$, which formed broad bands, could not be differentiated by the densitometer employed in the present investigations. These bands may be heterogeneous. The band of $0.8-1 \cdot 2 \mathrm{~kb}$ was the strongest among the four groups of bands in all the dietary groups. The band of $7.4 \mathrm{~kb}$ was remarkably weak in the groups of rats given diets $G$ and PF (Fig. 1 and Table 3; Expt 1). The bands of $2 \cdot 0$ and $3 \cdot 6-4.0 \mathrm{~kb}$ were also affected by diets $G$ and PF. The band of 0.8-1.2 kb decreased in the diet G-fed rats compared with the diet C-fed rats, but there was no significant difference between the rats given diet $G$ and diet PF. The mRNA of $0 \cdot 8-1 \cdot 2$ and $3.6-4.0 \mathrm{~kb}$ decreased significantly in the rats fed on diet ISP compared with that of rats given diet $\mathrm{C}$ (Table 3, Expt 2). This effect was not due to the difference in food intake. Supplementation of the soya-bean-protein diet with methionine (diet ISPM) increased the amount of mRNA species up to the level of the diet C-fed rats (Table 3, Expt 2).

\section{DISCUSSION}

It is well established that plasma immunoreactive IGF-1 concentration reflects the growth rate of animals fed on graded levels of dietary proteins or fed on proteins of different nutritional quality (Takahashi et al. 1990). The present results were consistent with this observation. The effect of nutritional quality of dietary proteins on plasma immunoreactive 
Table 3. Densitometric analysis of the results of Northern blot analysis* of insulin-like growth factor-1 (IGF-I) $m R N A$ in the liver of rats fed on diets containing casein $(C)$, isolated soyabean protein (ISP), isolated soya-bean protein supplemented with methionine (ISPM), gluten $(G)$ or a protein-free $(P F)$ diet $\dagger$

(Values are means for five rats expressed as the relative density of the bands shown in Figs 1 and 2)

\begin{tabular}{|c|c|c|c|c|c|}
\hline \multirow[b]{2}{*}{$\begin{array}{l}\text { Molecular species of mRNA ... } \\
\text { Diet }\end{array}$} & \multicolumn{5}{|c|}{ Relative density of the bands } \\
\hline & $0 \cdot 8-1 \cdot 2 \mathrm{~kb}$ & $2.0 \mathrm{~kb}$ & $3.6-4.0 \mathrm{~kb}$ & $7 \cdot 4 \mathrm{~kb}$ & Total \\
\hline \multicolumn{6}{|l|}{ Expt 1} \\
\hline $\mathrm{C}$ & $929^{\mathrm{b}}$ & $417^{b}$ & $376^{\mathrm{b}}$ & $610^{b}$ & $2331^{n}$ \\
\hline G & $617^{+15}$ & $174^{a}$ & $148^{a}$ & $62^{\mathrm{a}}$ & $1000^{2}$ \\
\hline $\mathrm{PF}$ & $509^{\mathrm{a}}$ & $253^{\mathrm{a}}$ & $108^{\mathrm{a}}$ & $149^{\mathrm{a}}$ & $1020^{4}$ \\
\hline Residual mean square & 29875 & 18113 & 5332 & 27714 & 270204 \\
\hline$F$ & II.4 & $8 \cdot 7$ & 60 & $7 \cdot 6$ & $12 \cdot 6$ \\
\hline $\begin{array}{l}\text { Statistical significance of effect } \\
\text { of diet: } P\end{array}$ & $<0.01$ & $<0.01$ & $<0.01$ & $<0 \cdot 01$ & $<0.01$ \\
\hline \multicolumn{6}{|l|}{ Expt $2 \ddagger$} \\
\hline $\mathrm{C}$ & $991^{\prime \prime}$ & $551^{\prime \prime}$ & $592^{\prime}$ & $437^{\prime \prime}$ & $2519^{p}$ \\
\hline ISPM & $895^{m}$ & $527^{\prime \prime}$ & $525^{\prime}$ & $482^{b}$ & $2430^{\mathrm{h}}$ \\
\hline ISP & $676^{a ! b}$ & $582^{b}$ & $387^{11}$ & $282^{a b}$ & $1928^{\mathrm{h}}$ \\
\hline $\mathrm{PF}$ & $404^{a}$ & $201^{\text {a }}$ & $91^{a}$ & $28^{: t}$ & $723^{a}$ \\
\hline Residual mean square & 39917 & 5990 & 8854 & 5208 & 148958 \\
\hline$F$ & 60 & 12.8 & 11.8 & $83 \cdot 3$ & $19 \cdot 5$ \\
\hline $\begin{array}{l}\text { Statistical significance of effect } \\
\text { of diet: } P\end{array}$ & $<0.01$ & $<0.01$ & $<0.01$ & $<0.01$ & $<0.01$ \\
\hline
\end{tabular}

a, b.c Values with unlike superscript letters within the same molecular species for each experiment were significantly different $(P<0 \cdot 05)$ by Tukey's $Q$ test (Snedecor \& Cochran, 1967).

* For details of procedures, see p. 259

$\dagger$ For details, see Table I and p. 258.

₹ Five randomly selected rats were used for Northern blot analysis.

IGF-1 concentration was not the effect of energy intake but the effect of dietary protein, because there was no significant difference in energy intake between the rats fed on diet ISP and those fed on diet $\mathrm{C}$ (the diets were practically isoenergetic). Using a bioassay system of somatomedin, Bolze et al. (1985) also showed that lysine, methionine or histidine deficiency decreased IGF concentration. However, they did not conclude that some special amino acid deficiency induced this decrease in IGF concentration. Maes et al. (1988) showed the important role of nutritional factors affecting the plasma immunoreactive IGF-1 concentration. They showed that GH administration to hypophysectomized rats induced an increase in plasma IGF-1 concentration in the well-nourished rats (those fed on a diet containing $150 \mathrm{~g}$ protein $/ \mathrm{kg}$ diet) but not in the protein-deficient rats (those fed on a diet with $50 \mathrm{~g}$ protein $/ \mathrm{kg}$ diet). Furthermore, Maiter et al. (1989) concluded that the effect of dietary protein on plasma IGF-1 concentration is not due to the decreased growth hormone concentration or the decreased number of growth hormone or insulin receptors on the cell surface but, instead, is due to the post-receptor defect of growth hormone action. These results clearly show that nutritional factors are important in regulating the plasma concentration of IGF-1. However, the mechanism which regulates the plasma IGF-1 concentration has not yet been elucidated.

A likely way to regulate plasma IGF-1 concentration may be the rate of production and secretion of IGF-1 by the liver. If the production and secretion of IGF-1 by the liver is 
correlated with the mRNA content in the liver, the quantity and nutritional quality of dietary proteins will affect the IGF-1 mRNA content in the liver. The present findings indicate how liver mRNA content is regulated by dietary proteins. The livers of rats fed on a protein of good nutritional quality (casein) had the highest levels of IGF-1 mRNA and those of rats given a protein of low nutritional quality (gluten) or those fed on a proteinfree diet had far lower levels of mRNA. The rats fed on diet ISP (soya-bean-protein) had lower levels of some mRNA species than those fed on the same diet supplemented with methionine (diet ISPM).

Emler \& Schalch (1987) reported that the liver IGF-1 mRNA content decreases during fasting and increases after refeeding to a level 3-fold that of the prefasting period. In the present study a decrease in IGF-1 mRNA was observed in diet G-fed rats, under marginal lysine and threonine deficiency, and in diet ISP-fed rats under marginal methionine deficiency. This finding suggests that IGF-1 mRNA levels in the liver are sensitive to nutritional status, or even to a marginal deficiency of some nutrients. Whether the changes in IGF-1 mRNA content in liver are caused by the rate of transcription of the IGF-1 gene or by the factors affecting the stability of IGF-1 mRNA remains to be elucidated.

As reported in the present paper and by other investigators (Roberts et al. 1986; Murphy et al. 1987), four or five species of IGF-1 mRNA have been identified in rat liver. Since only one IGF-1 gene has been demonstrated in rat liver (Shimatsu \& Rotwein, 1987a), the four or five species of IGF-1 mRNA must be derived from a single gene of IGF-1. In other words, the different species are supposed to be produced by different splicing or different use of multiple polyadenylation sites of single nuclear RNA, or by different points of initiation of gene transcription. The heterogeneity of molecular species of mRNA may be explained by the heterogeneity of the $5^{\prime}$-upstream nucleotide sequence. There are three or four kinds of 5'-upstream structure in IGF-1 mRNA (Roberts et al. 1987; Shimatsu \& Rotwein, $1987 \mathrm{~b}$; Kato et al. $1990 \mathrm{~b}$ ). However, recent studies suggest that the difference in the structure of the nucleotide sequence in 5'-upstream region is not the principal reason for the difference in the molecular size of IGF-1 mRNA, but the difference in the structure of the 3'-downstream region is (Lund et al. 1989; Kato et al. 1990 a). This means that each size of mRNA is composed of two or three kinds of mRNA of different 5 -upstream structure (Hoyt et al. 1988).

The physiological role of these different mRNAs has not been elucidated. Moats-Staats et al. (1989) showed that artificially raised rats contained more $7.5 \mathrm{~kb}$ mRNA in liver than those raised by their mothers. Furthermore, Emler \& Schalch (1987) reported that $7.5 \mathrm{~kb}$ mRNA changed most extensively under a fasting-refeeding cycle. By contrast, growth hormone induces an increase in all the species of mRNA equally (Roberts et al. 1986). More recently, Straus \& Takemoto (1990) also showed that all the bands decreased under fasting. The effect of other physiological factors on the different species of mRNA has also been reported by other workers (Doglio et al. 1987). These findings suggest that each mRNA species has its specific pattern of response to physiological factors. The present findings add further evidence for a specific physiological significance for each molecular species of IGF-1 mRNA.

The present study shows that protein deprivation or feeding a marginal essential amino acid-deficient diet (diet G) decreased the contents of IGF-1 mRNA of relatively large size (i.e. $7 \cdot 4 \mathrm{~kb}$ ) more markedly than those of smaller sizes, although the possibility that this effect was induced by the difference in food intake cannot be excluded. This conclusion can be reached by calculating the amount of each molecular species of mRNA divided by the total (sum) amount of IGF-1 mRNA for each rat. The amount of $7.4 \mathrm{~kb}$ mRNA divided by the total amount of IGF-1 mRNA in the rats given diets $P F$ or $\mathrm{G}$ was significantly lower than that in the rats given diet $\mathrm{C}(P<0.05$ by Tukey's $\mathrm{Q}$ test). This suggests that the status 
of protein nutrition primarily affects the level of larger mRNA of IGF-1 (see also MoatsStaats et al. 1989). Their findings, together with ours, suggest that splicing of mRNA precursor, termination point of transcription, or different use of the polyadenylation site, is regulated by nutritional or hormonal conditions of animals. Another possibility is that $7.4 \mathrm{~kb}$ mRNA is more unstable under poor nutritional conditions. Straus \& Takemoto (1990) recently reported that the decrease in IGF-1 mRNA in fasted animals is not due to the rate of transcription but due to the post-transcriptional events (e.g. the stability of mRNA). Further studies on the rate of transcription of the IGF-1 gene, the mode of splicing of the precursor RNA, the stability of mRNA species within hepatocytes, or the regulation of translation of mRNA will elucidate the role of liver in the regulation of IGF-1 concentration in plasma.

\section{REFERENCES}

American Institute of Nutrition (1977). Report of the AIN Ad Hoc Committee on Standards for Nutritional Studies. Journal of Nutrition 107, 1340-1348.

Bolze, M. S., Reevers, R. D., Lindbeck, F. E. \& Eldeers, M. J. (1985). Influence of selected amino acid deficiencies on somatomedin, growth and glycosaminoglycan metabolism in weanling rats. Journal of Nutrition 115, 782-787.

Chomczynski, P. \& Sacchi, N. (1987). Single-step method of RNA isolation by acid guanidinium thiocyanatephenol-chloroform extraction. Analytical Biochemistry 162, 156-159.

D'Ercole, A. J., Stiles, A. D. \& Underwood, L. E. (1984). Tissue concentrations of somatomedin C: further evidence for multiple sites of synthesis and paracrine or autocrine mechanisms of action. Proceedings of the National Academy of Sciences, U.S.A. 81, 935-939.

Doglio, A., Dani, C., Fredrikson, G., Grimaldi, P. \& Ailhaud, G. (1987). Acute regulation of insulin-like growth factor-I gene expression by growth hormone during adipose cell differentiation. EMBO Journal 6, 4011-4016.

Emler, C. A. \& Schalch, D. S. (1987). Nutritionally-induced changes in hepatic insulin-like growth factor I (IGF-1) gene expression in rats. Endocrinology 120, 832-834.

Froesch, E. R., Schmid, C., Schwander, J. \& Zapf, J. (1985). Actions of insulin-like growth factors. Annual Review of Physiology 47, 443-467.

Hoyt, E. C., Van Wyk, J. J. \& Lund, P. K. (1988). Tissue and development specific regulation of a complex family of rat insulin-like growth factor-I messenger ribonucleic acids. Molecular Endocrinology 2, 1077-1086.

Isley, W. L., Underwood, L. E. \& Clemmons, D. R. (1983). Dietary components that regulate serum somatomedin-C concentrations in humans. Journal of Clinical Investigation 71, 175-182.

Kato, H., Okoshi, A., Miura, Y. \& Noguchi, T. (1990a). A new cDNA clone relating to larger molecular species of rat insulin-like growth factor-I mRNA. Agricultural and Biological Chemistry 54, 1599-1601.

Kato, H., Takenaka, A., Miura, Y., Nishiyama, M. \& Noguchi, T. (1990 b). Evidence of introduction by molecular cloning of artificial inverted sequence at the $5^{\prime}$ terminus of the sense strand of rat insulin-like growth factor-I cDNA. Agricultural and Biological Chemistry 54, 2225-2230.

Lund, P. K., Hoyt, E. C. \& Van Wyk, J. J. (1989). The size heterogeneity of rat insulin-like growth factor-I mRNAs is due primarily to differences in the length of $3^{\prime}$-untranslated sequence. Molecular Endocrinology 3, 2054-2061.

Maes, M., Amand, Y., Underwood, L. E., Maiter, D. \& Ketelslegers, J.-M. (1988). Decreased serum insulin-like growth factor I response to growth hormone in hypophysectomized rats fed a low protein diet: evidence for a postreceptor defect. Acta Endocrinologica 117, 320-326.

Maiter, D., Fliesen, T., Underwood, L. E., Maes, M., Gerard, G., Davenport, M. I. \& Ketelslegers, J.-M. (1989). Dietary protein restriction decreases insulin-like growth factor I independent of insulin and liver growth hormone binding. Endocrinology 124, 2604-2611.

Maniatis, T., Fritseh, E. F. \& Sambrook, J. (editors) (1982). Electrophoresis of RNA through gels containing formaldehyde. In Molecular Cloning. A Laboratory Manual pp. 202-203. New York: Cold Spring Harbor Laboratory.

Moats-Staats, B. M., Brady, J. L. Jr, Underwood, L. E. \& D'Ercole, A. J. (1989). Dietary protein restriction in artificially reared neonatal rats causes a reduction of insulin-like growth factor-I gene expression. Endocrinology $125,2368-2374$.

Murphy, L. J., Bell, G. I. \& Friesen, H. G. (1987). Tissue distribution of insulin-like growth factor I and II messenger ribonucleic acid in the adult rat. Endocrinology 120, 1279-1282.

Phillips, L. S., Orawski, A. T. \& Belosky, D. C. (1978). Somatomedin and nutrition. IV. Regulation of somatomedin activity and growth cartilage activity by quantity and composition of diet in rats. Endocrinology $103,121-127$.

Prewitt, T. E., D'Ercole, A. J., Switzer, B. R. \& Van Wyk, J. J. (1982). Relationship of serum immunoreactive somatomedin-C to dietary proteins and energy in growing rats. Journal of Nutrition 112, 144150. 
Rinderknecht, E. \& Humbel, R. E. (1978). The amino acid sequence of human insulin-like growth factor I and its structural homology with proinsulin. Journal of Biological Chemistry 253, 2769-2776.

Roberts, C. T. Jr, Brown, A. L., Graham, D. E., Seelig, S., Berry, S., Gabbay, K. H. \& Rechler, M. M. (1986). Growth hormone regulates the abundance of insulin-like growth factor I RNA in adult rat liver. Journal of Biological Chemistry 261, $10025 \cdots 10028$.

Roberts, C. T. Jr, Lasky, S. R., Lowe, W. L. Jr \& LeRoith, D. (1987). Rat IGF-I cDNAs contain multiple 5'untranslated regions. Biochemical and Biophysical Research Communications 146, 1154-1159.

Rogers, Q. R. \& Harper, A. E. (1965). Amino acid diets and maximal growth in the rat. Journal of Nutrition 87 , 217-225.

Schwander, J. C., Hauri, C., Zapf, J. \& Froesch, E. R. (1983). Synthesis and secretion of insulin-like growth factor and its binding protein by the perfused rat liver: Dependence on growth hormone status. Endocrinology 113, 297-305.

Shimatsu, A. \& Rotwein, P. (1987a). Mosaic evolution of the insulin-like growth factors: Organization, sequence and expression of the rat insulin-like growth factor I gene. Journal of Biological Chemisty 262, $7894-7900$.

Shimatsu, A. \& Rotwein, P. (1987b). Sequence of two rat insulin-like growth factor I mRNA differing within the 5'-untranslated region. Nucleic Acids Research 15, 7196.

Snedecor, G. W. \& Cochran, W. G. (1967). One-way classifications. Analysis of variance. In Statistical Methods, 6th ed, pp. 271-273. Ames, Iowa: Iowa State University Press.

Straus, D. S. \& Takemoto, C. D. (1990). Effect of fasting on insulin-like growth factor-I (IGF-I) and growth hormone receptor mRNA levels and IGF-I gene transcription in rat liver. Molecular Endocrinology 4, 91-100.

Takahashi, S., Kajikawa, M., Umezawa, T., Takahashi, S.-L., Kato, H., Miura, Y., Nam, T. J., Noguchi, T. \& Naito, H. (1990). Effect of dietary proteins on the plasma immunoreactive insulin-like growth factor1 somatomedin C concentration in the rat. British Journal of Nutrition 63, 521-534.

Van Wyk, J. J. (1984). The somatomedins: Biological actions and physiologic control mechanisms. In Hormonal Proteins and Peptides, vol. XII, pp. 81-125. New York and London: Academic Press. 